\title{
Neurotransmitter $\gamma$-aminobutyric acid-mediated inhibition of the invasive ability of cholangiocarcinoma cells
}

\author{
QIANG HUANG* , CHENHAI LIU*, CHENG WANG, YUANGUO HU, LUJUN QIU and PENG XU \\ Department of General Surgery, Affiliated Provincial Hospital of Anhui Medical University, Hefei 230001, P.R. China
}

Received October 25, 2010; Accepted January 17, 2011

DOI: $10.3892 / \mathrm{ol} .2011 .263$

\begin{abstract}
The present study aimed to investigate the effect and mechanism of $\gamma$-aminobutyric acid (GABA) on the bionomics of cholangiocarcinoma QBC939 cells. A transwell cell culture chamber assay in vitro was used to detect the ability of invasion and metastasis of cholangiocarcinoma QBC939 cells. The expression of matrix metalloproteinase (MMP) mRNA and the enzymatic activity in QBC939 cells were detected by reverse transcription-polymerase chain reaction and gelatin zymography, respectively. Different concentrations of GABA inhibited the ability of the tumor cells in trans-Matrigel migration $(100 \mu \mathrm{mol} / \mathrm{l} \mathrm{GABA}, 60 \pm 9.54$ vs. $42.67 \pm 4.04, \mathrm{P}<0.05)$, and inhibited the activity and expression of MMP-2 and MMP-9. GABA inhibited the invasion and metastasis of cholangiocarcinoma QBC939 cells, and the mechanism may involve the down-regulation of the activity of MMPs.
\end{abstract}

\section{Introduction}

Increasing evidence suggests that the migration of tumor cells is not solely a consequence of genetic alterations, but is regulated by various epigenetic factors. Chemokines, neurotransmitters, and other structurally non-related ligands of serpentine receptors are known to be significant initiators of migratory activity (1). With the development of neurobiology, research has revealed that neurotransmitters are involved in the growth and development of carcinoma $(2,3) \cdot \gamma$-aminobutyric acid (GABA) was originally identified as a principal inhibitory neurotransmitter in the adult mammalian brain. It has, however, become clear that GABA and GABA receptors exist in a number of non-neuronal peripheral tissues $(4,5)$, including the biliary tract system (6). Moreover, findings of previous studies showed that the expression of GABA and its synthetic enzyme,

Correspondence to: Dr Qiang Huang, Department of General Surgery, Affiliated Provincial Hospital of Anhui Medical University, No. 17 Lujiang Road, Hefei 230001, P.R. China

E-mail: hq_sohu@sohu.com

${ }^{*}$ Contributed equally

Key words: cholangiocarcinoma, $\gamma$-aminobutyric acid, matrixmetalloproteinase, neoplasm invasiveness, telomerase
GAD, were significantly increased in neoplastic tissues, such as colorectal carcinoma, breast cancer and gastric cancer, as compared with normal tissues (4,7-9). Furthermore, GABA was found to be related to the invasion and metastasis of cancer cells (10), although the effect is different among various tumor types; this effect involves promotion in prostate cancer (11) and inhibition in colon carcinoma (12). Previously, we reported on the inhibition of proliferation of cholangiocarcinoma cells by GABA (13). Since the manner in which GABA affects the invasion and metastasis of cholangiocarcinoma cells remains to be determined, this study aimed to investigate the effect of GABA on the regulation of cholangiocarcinoma cell migration and to describe its mechanism of action. A secondary aim was to determine whether the disposition played any role in the progression of the disease.

\section{Materials and methods}

Materials. Cholangiocarcinoma QBC939 cells (14) were provided by Dr Shu-Guang Wang (Hepatobiliary Surgery Institute of Chinese PLA, The Third Military Medical University, Chongqing, China). GABA was produced by Sigma Company (St. Louis, MO, USA), and it was diluted to concentrations of $1,10,100$ and $1000 \mu \mathrm{mol} / 1$, respectively.

\section{Methods}

Cell culture. Cholangiocarcinoma QBC939 cells were cultured at $37^{\circ} \mathrm{C}$ in RPMI-1640 supplemented with fetal calf serum $(100 \mathrm{ml} / \mathrm{l})$, penicillin $\left(100 \times 10^{3} \mathrm{U} / \mathrm{l}\right)$, streptomycin (100 $\mathrm{mg} / \mathrm{l})$ and L-glutamine $(2 \mathrm{mmol} / \mathrm{l})$. The $\mathrm{pH}$ was maintained at 7.2-7.4 by equilibration with $5 \% \mathrm{CO}_{2}$. The QBC939 cells were subcultured with EDTA, and the cells used in the experiment were in the exponential growth phase.

Cell adhesion assay. Cells in 96-well plates were incubated at $37^{\circ} \mathrm{C}$ with Matrigel for $1 \mathrm{~h}$ and then blocked with phosphate-buffered saline (PBS) containing $10 \mathrm{~g} / 1$ bovine serum albumin (BSA) for another $1 \mathrm{~h}$ at the same temperature. The QBC939 cells were exposed to different concentrations of $\operatorname{GABA}(1,10,100$ and $1000 \mu \mathrm{mol} / \mathrm{l})$ for $24 \mathrm{~h}$ and were suspended in serum-free medium at a density of $1 \times 10^{5}$ cells/ $\mathrm{ml}$. Then, $0.1 \mathrm{ml}$ of the QBC939 cell suspension was added to each well, and incubation was carried out at $37^{\circ} \mathrm{C}$ for $1 \mathrm{~h}$. The plates were washed three times with PBS to remove the unattached cells. The remaining QBC939 cells in the 
Table I. Primer sequences and sizes of the expected PCR products.

\begin{tabular}{|c|c|c|c|}
\hline Primer & & Sequence & Length (bp) \\
\hline \multirow[t]{2}{*}{ MMP-2 } & Sense & 5'-CCACGTGACAAGCCCATGGGGCCCC-3' & 480 \\
\hline & Antisense & 5'-GCAGCCTAGCCAGTCGGATTTGATG-3' & \\
\hline \multirow[t]{2}{*}{ MMP-9 } & Sense & 5'-GCCACTTGTCGGCGATAAGG-3' & 243 \\
\hline & Antisense & 5'-CACTGTCCACCCCTCAGAGC-3' & \\
\hline \multirow[t]{2}{*}{$\beta$-actin } & Sense & 5'-TGACGGGGTCACCCACACTGTGCCCATCTA-3' & 610 \\
\hline & Antisense & 5'-CTAGAAGCATTTGCGGTGGACAATGGAGGG-3' & \\
\hline
\end{tabular}

96-well plates were reacted with MTT assay for $4 \mathrm{~h}$ at $37^{\circ} \mathrm{C}$, solubilized with DMSO, and the absorbance of each well was measured at $492 \mathrm{~nm}$ with a Biocell HT1 microplate reader. Results were expressed as the percentage of total cells, assuming that the adhesion of cells in the control represented $100 \%$.

In vitro invasion assay. An invasion assay assessing the ability of cells to invade a synthetic basement membrane was performed in transwell chambers (Costar Co., USA) with a polycarbonate filter $(6.5-\mathrm{mm}$ pore size) separating the upper and lower chambers. The top surface of the polycarbonate filter was coated with Matrigel, and the bottom with fibronectin. QBC939 cells $\left(1 \times 10^{5}\right)$ treated with different concentrations of $\operatorname{GABA}(1,10,100$ and $1000 \mu \mathrm{mol} / \mathrm{l})$ for $24 \mathrm{~h}$ were added to the upper transwell chamber in $100 \mathrm{ml}$ of serum-free RPMI-1640 containing $0.1 \%$ BSA, while $600 \mathrm{ml}$ of serum-free BSA-RPMI-1640 was added to the lower chamber. After $4 \mathrm{~h}$, the filters were fixed in methanol and stained with hematoxylin and eosin. The non-invading cells on the top surface of the filter membrane were removed with a cotton swab. Cells on the bottom surface of the filter were counted, and the mean number of cells was determined from five high-power fields under a light microscope. The inhibitory rate (IR) was calculated as: IR $(\%)=$ number of invasive cells in the negative control group - number of invasive cells in the test groups/number of invasive cells in the negative control group x 100 .

Measurement of matrix metalloproteinases (MMPs) by reverse transcription-polymerase chain reaction (RT-PCR). QBC939 cells were treated with different concentrations of GABA $(1,10$, 100 and $1000 \mu \mathrm{mol} / \mathrm{l})$ for $24 \mathrm{~h}$ and collected by centrifugation. Total RNA was isolated using TRIzol reagent according to the manufacturer's instructions. The concentrations and purity of the total RNA were determined using the DUR 640 nucleic acid and protein analyzer (Beckman, Coulter, Fullerton, CA, USA). The first-strand cDNA was synthesized from $5 \mu \mathrm{g}$ of total RNA using 50 pmol of oligo (dT) primers, 10 units of AMV reverse transcriptase XL, 20 units RNase inhibitor, $5 \mathrm{X}$ buffer and $10 \mathrm{mmol} / \mathrm{l}$ each dNTP in a total volume of $20 \mu \mathrm{l}$. PCRs were performed using the respective primers for MMP-2, MMP-9 and $\beta$-actin. The primer sequences which were obtained from GenBank are listed in Table I. PCR was carried out in a 25- $\mu$ l volume containing $4 \mu 1$ of CDNA template, 10X PCR buffer, $20 \mu \mathrm{mol} / 1$ of each primer, $2.5 \mathrm{mmol} / 1 \mathrm{dNTP}$ mixture, and
2.5 units of Taq polymerase. Following denaturation at $96^{\circ} \mathrm{C}$ for $3 \mathrm{~min}$, the reaction mixtures were subjected to 35 cycles of PCR amplification in a PCT-100 ${ }^{\mathrm{TM}}$ programmable thermal controller. Each cycle consisted of $45 \mathrm{sec}$ of denaturation at $94^{\circ} \mathrm{C}$, a primer specific annealing temperature and period (at $5^{\circ} \mathrm{C}$ for $45 \mathrm{sec}$ ) and extension at $72^{\circ} \mathrm{C}(1 \mathrm{~min})$.

The amplified products were separated in $20 \mathrm{~g} / \mathrm{l}$ agarose gel and stained with ethidium bromide. Following electrophoresis, the gel was observed, and images were captured under an ultraviolet reflector. The density and area of each band were analyzed using ChemiImager ${ }^{\mathrm{TM}} 4000$ digital system (Alpha Innotech, San Leandro, CA, USA).

Zymography. Zymography was used for the analysis of MMP activity secreted into the culture medium of the cell line, as previously described (15). QBC939 cells were seeded at a density of $5 \times 10^{4}$ cells/pore in 24-well plates and maintained in $400 \mu \mathrm{l}$ of serum-free medium containing different concentrations of GABA $(1,10,100$,and $1000 \mu \mathrm{mol} / \mathrm{l})$ for $24 \mathrm{~h}$. Following centrifugation at $500 \mathrm{~g}$ for $10 \mathrm{~min}$, the supernatant was collected and stored at $-20^{\circ} \mathrm{C}$. SDS-PAGE was performed on gradient gels that contained $1.0 \mathrm{~g} / \mathrm{l}$ gelatin and run for 3-4 $\mathrm{h}$ under non-denaturing conditions. Following electrophoresis, the gels were incubated in $2.5 \%$ Triton $\mathrm{X}-100$ for $1 \mathrm{~h}$ and then incubated in substrate buffer [50 $\mu \mathrm{mol} / 1 \mathrm{Tris}(\mathrm{pH} 7.5)$, $10 \mathrm{mmol} / 1 \mathrm{CaCl}_{2}, 200 \mathrm{mmol} / \mathrm{l} \mathrm{NaCl}$ and $\left.1 \mu \mathrm{mol} / 1 \mathrm{ZnCl}_{2}\right]$ for $18 \mathrm{~h}$ at $37^{\circ} \mathrm{C}$. Following incubation, the gels were stained in a solution containing $1 \mathrm{~g} / 1$ Coomassie blue R250 for $4 \mathrm{~h}$ and destained with $45 \%$ methanol and $10 \%$ acetic acid until clear bands were noted.

Statistical analysis. Data were expressed as the mean \pm SD. Data analysis was performed using the one-way ANOVA and the Student's t-test. $\mathrm{P}<0.05$ was considered to be statistically significant.

\section{Results}

Effect of GABA on the attachment ability of QBC939 cells. As shown in Fig. 1, the rate of attachment to Matrigel was decreased as the concentration of GABA was increased. At the concentration of $10 \mu \mathrm{mol} / 1 \mathrm{GABA}$, the rate of cell attachment was significantly lower than that of the negative control group $(\mathrm{P}<0.05)$, and the inhibitory rate was $10.9 \%$. The inhibitory effect was positively correlated with the concentration of GABA. 
Table II. Effect of $\gamma$-aminobutyric acid on the invasive ability of QBC939 cells.

\begin{tabular}{lcc}
\hline Groups & $\begin{array}{c}\text { Cell number } \\
(\text { mean } \pm \text { SD) }\end{array}$ & $\begin{array}{c}\text { Inhibitory } \\
\text { frequency (\%) }\end{array}$ \\
\hline Negative control & $60.00 \pm 9.54$ & 0 \\
$1 \mu \mathrm{mol} / 1 \mathrm{GABA}$ & $58.33 \pm 4.04$ & 2.78 \\
$10 \mu \mathrm{mol} / 1$ & $50.33 \pm 5.51$ & 16.12 \\
$100 \mu \mathrm{mol} / 1$ & $42.67 \pm 4.04^{\mathrm{a}}$ & 28.88 \\
$1000 \mu \mathrm{mol} / 1$ & $39.33 \pm 3.52^{\mathrm{a}}$ & 34.45 \\
\hline
\end{tabular}

${ }^{a} \mathrm{P}<0.05$, compared with the negative control group. GABA, $\gamma$-aminobutyric acid.

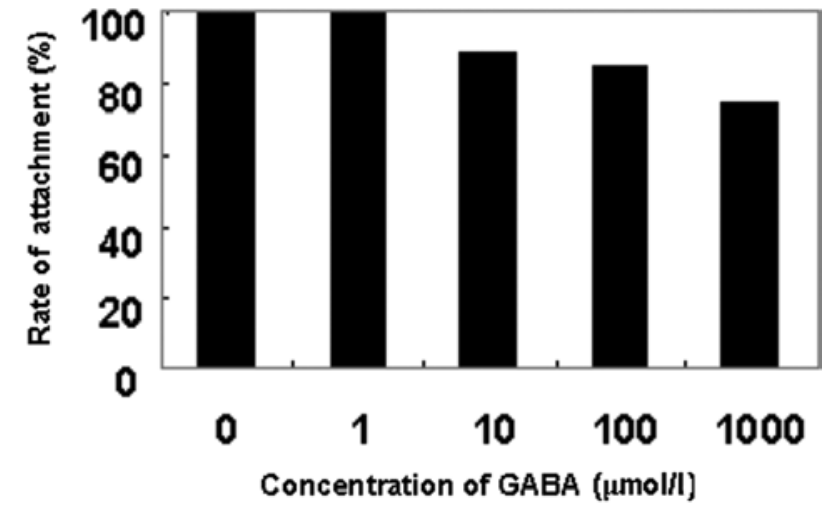

Figure 1. Effect of GABA on the attachment ability of QBC939 cells.

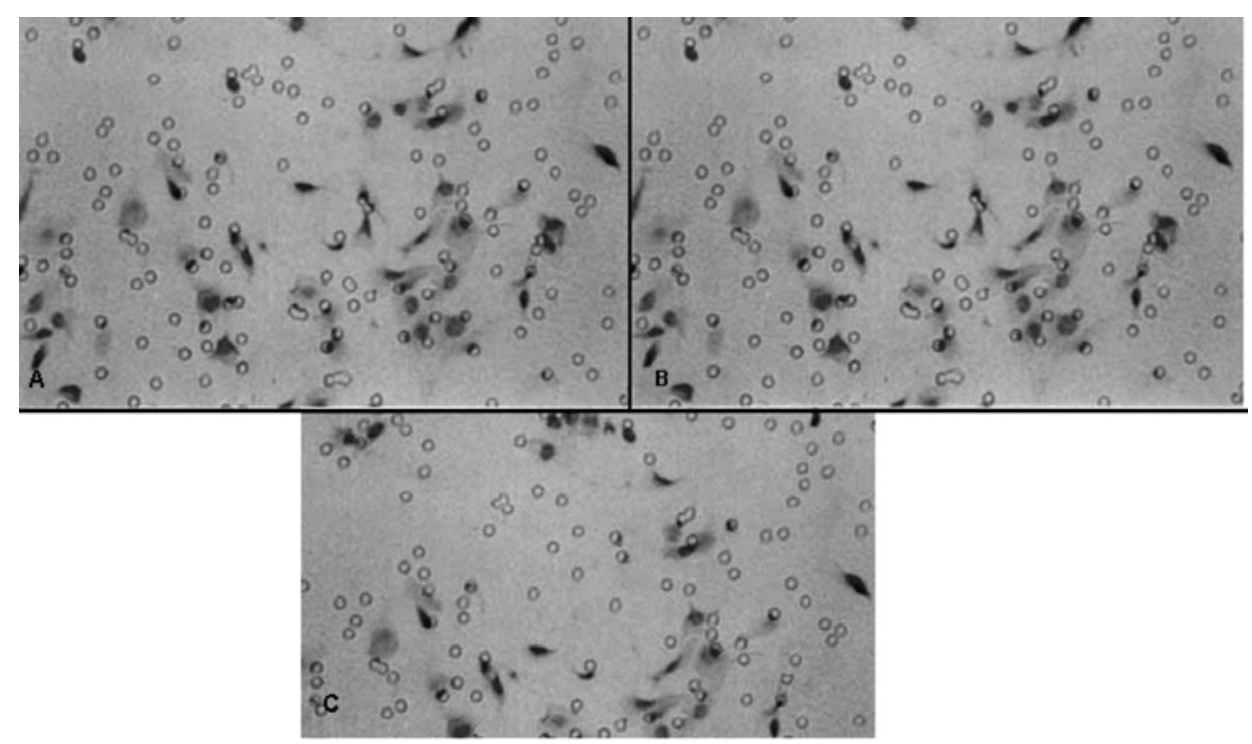

Figure 2. Effect of GABA on the invasion of QBC939 cells detected by a reconstituted basement membrane invasion assay (magnification, $\mathrm{x} 200$ ). (A) Negative control group. (B) Fewer invading QBC939 cells are noted in the $100 \mu \mathrm{mol} / 1$ GABA group when compared to the negative control group. (C) Even fewer invading QBC939 cells are noted in the $1000 \mu \mathrm{mol} / 1 \mathrm{GABA}$ group when compared to the negative control group.

Effect of GABA on the invasive ability of QBC939 cells. Table II shows that the invasive abilities of the QBC939 cells treated with 100 and $1000 \mu \mathrm{mol} / 1$ of GABA were significantly lower than that of the negative control group $(\mathrm{P}<0.01)$, and the inhibitory rates were 28.88 and $34.45 \%$, respectively. At $10 \mu \mathrm{mol} / 1 \mathrm{GABA}$, the inhibitory rate was $16.12 \%$, but no statistical significance was noted when compared to the negative control group ( $\mathrm{P}>0.05)$. The effect of GABA on the invasive ability of QBC939 cells is shown in Fig. 2.

Effect of GABA on collagenase activity in QBC939 cells. As shown in Figs. 5 and 6, MMP-2 and MMP-9 expression was detected in the serum-free medium supernatant of the QBC939 cells. Moreover, the activity of MMP-2 was stronger than that of MMP-9. At concentrations of 10, 100 and $1000 \mu \mathrm{mol} / 1$, GABA significantly reduced MMP-9 (92 kDa type IV collagenase) and MMP-2 (72-kDa type II collagenase) activity in a dose-dependent manner. However, at $1 \mu \mathrm{mol} / \mathrm{l} \mathrm{GABA}$, the collagenase activity did not differ from that in the negative control group (Figs. 3 and 4).
Effect of GABA on the expression of MMP-2 and MMP-9 mRNA in QBC939 cells. The expression of MMP-2 and MMP-9 mRNA of QBC939 cells treated at different concentrations of GABA decreased in comparison with that of the negative control group. As the concentrations of GABA increased, the expression of MMP-2 and MMP-9 mRNA was down-regulated. Moreover, the decrease in MMP-2 mRNA expression was more evident (Figs. 5 and 6).

\section{Discussion}

Our previous study (13) showed that GABA inhibits the proliferation of cholangiocarcinoma QBC939 cells in vitro, which is in accordance with its effects in other types of cancer. However, the effect of GABA on cancer metastasis was found to vary in different types of cancer. No report currently exists on the effect of GABA in cholangiocarcinoma.

The present study is the first to prove that GABA inhibits the metastasis of cholangiocarcinoma QBC939 cells in vitro. Cancer metastasis involves a complex cascade of events 


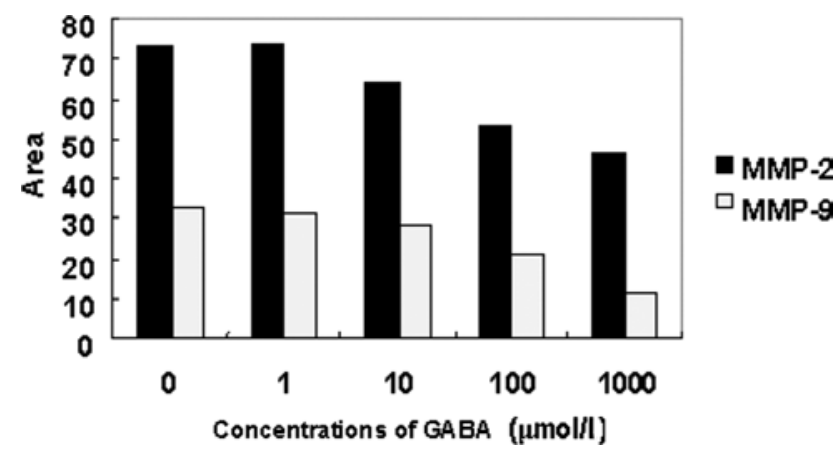

Figure 3. Quantitation of the levels of 92- and 72-kDa type IV collagenase in the QBC939 cells by ChemiImager 4000.

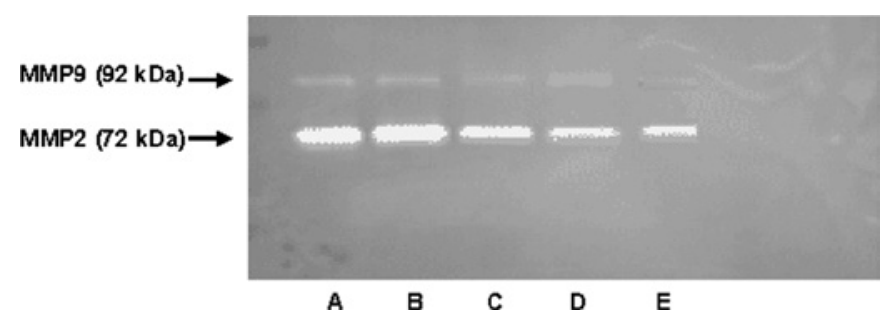

Figure 4. Effects of (B) 1, (C) 10, (D) 100 and (E) $1000 \mu \mathrm{mol} / 1 \mathrm{GABA}$, respectively, on gelatinase secretion in QBC939 cells detected by zymography. $\mathrm{A}$, the negative control group.

involving tumor dissemination from the primary site to distant organs. Cancer cells must detach from the primary tumor, invade stromal tissue, enter the circulation, extravasate and invade the target organ, forming a metastatic colony. This increase or decrease in heterotypic adhesion to a basement membrane has been defined as the critical event of tumor invasion that signals the initiation of the metastatic cascade $(16,17)$. In the present study, heterotypic adhesion of QBC939 cells to the artificial basement membrane, Matrigel, was examined using an MTT dye assay to stain adhered cells. Results showed that GABA dose-dependently decreased the adhesive rate of QBC939 cells. Moreover, we utilized an invasion assay using transwell chambers to assess the ability of cells to invade a synthetic basement membrane. The results showed that the invasive ability of the QBC939 cells to the basement membrane was decreased in the two experiments confirming that GABA inhibits the invasive ability of QBC939 cells.

Proteolytic degradation of the extracellular matrix is a key step in invasion, and MMPs are shown to be crucial proteinases that enable tumor cells to permeate the basement membrane and invade surrounding tissues. MMPs are a family of highly homologous protein-degrading zinc-dependent enzyme endopeptidases. This family currently includes more than 25 members which can be divided into collagenases (MMP-1, -8 and -13), gelatinases (MMP-2 and -9), stromelysins (MMP-3 and -10), matrilysins (MMP-7 and -26) and the membrane-type MMPs (MMP-14 to -17 and -24). In the present study, expression of MMP-2 mRNA and MMP-9 mRNA was detected in the serum-free medium supernatant of QBC939 cells although the activity of MMP-9 was lower than that of MMP-2. Following treatment with GABA, the expression of

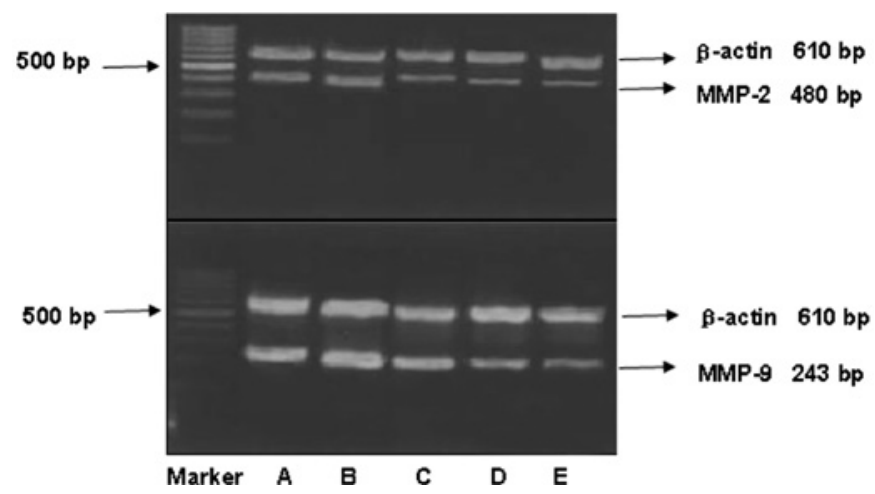

Figure 5. Effects of (B) 1, (C) 10, (D) 100 and (E) $1000 \mu \mathrm{mol} / 1 \mathrm{GABA}$, respectively, on the expression of MMP-2 and MMP-9 mRNA in QBC939 cells as detected by RT-PCR. A, the negative control group.

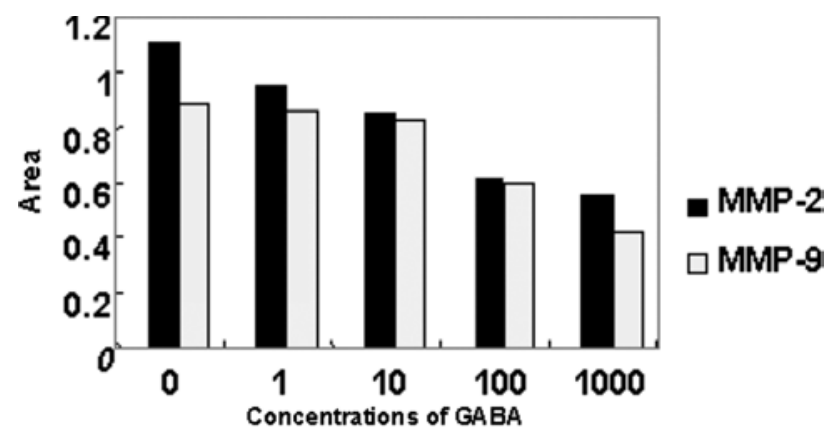

Figure 6. Quantitation of MMP-2 and MMP-9 mRNA levels in the QBC939 cells using ChemiImager 4000 .

MMP-2 and MMP-9 mRNA of QBC939 cells was decreased as was their activity. These results showed that GABA inhibits the invasion and metastasis of cholangiocarcinoma cells in vitro, and the mechanism of this effect was the inhibition of the expression and activity of MMP-2 and MMP-9. Moreover, MMP-2 activity was a more important factor in this effect. These findings indicate that GABA stimulation promotes cancer cell invasion and that GABA-induced cancer cell invasion is attributable to an increase in MMP-2 and MMP-9.

Collectively, based on the findings of our study and that of previous literature, GABA production was found to be enhanced by an increase in diamines, polyamines and activity of diamine oxidase. In the present study, an increase in GABA secretion inhibited malignant cell proliferation and invasion. These findings prove that the increase in content, production, and secretion of GABA may constitute a cell response and an immune defense mechanism against tumor development. However, even when malignant cells produce high GABA concentrations, such levels are much lower $(18,19)$ than the doses of neuropeptides required to inhibit cancer cell proliferation. Thus, we suggest that the increased production of GABA by tumoral cells is insufficient to block tumor growth, since inadequate concentrations of the neuropeptide are achieved. These results also provided us with theoretical proof that a good state of mind is helpful for the rehabilition of disease or may slow the progression of disease, particularly in cancer. 
In conclusion, the present results indicate that GABA inhibits cancer cell invasion, and a decrease in MMP-2 and MMP-9 activity is the underlying mechanism of action. Although findings of previous studies showed that inhibition of MMP activity may not adequately prevent cancer growth or metastasis (20), further investigation is required. Activation of the GABA-mediated pathway, possibly combined with MMP inhibition, exhibits potential therapeutic value to prevent cancer progression or metastasis and may warrant further attention, particularly for the treatment of cancer patients with metastasis.

\section{References}

1. Entschladen F, Lang K, Drell TL, Joseph J and Zanker KS: Neurotransmitters are regulators for the migration of tumor cells and leukocytes. Cancer Immunol Immunother 51: 467-482, 2002.

2. Li L, Gang C and Zhang GY: Effects of neurotransmitters on the proliferation of human hepatocytes. Chin J Bases Clin General Surg 9: 238-241, 2002.

3. Wu Fy, Ou ZL and Shao ZM: Classical neurotransmitter and cancer metastasis. Foreign Medical Sciences (Oncology section) 32: 678-680, 2005.

4. Watanabe M, Maemura K, Kanbara K, Tamayama $T$ and Hayasaki H: GABA and GABA receptors in the central nervous system and other organs. Int Rev Cytol 213: 1-47, 2002.

5. Roberts E: Adventures with GABA: fifty years on. In: GABA in the Nervous System. The View at Fifty Years. Martin D and Olsen R (eds). Lippincott Williams and Wilkins, Philadelphia, pp1-24, 2000.

6. Saito N, Taniyama K and Tanaka C: Uptake and release of gamma-aminobutyric acid in guinea pig gallbladder. Am J Physiol Gastrointest Liver Physiol 249: G192-G196, 1985.

7. Maemura K, Yamauchi H, Hayasaki H, et al: Gamma-aminobutyric acid immunoreactivity in intramucosal colonic tumors. J Gastroenterol Hepatol 18: 1089-1094, 2003.

8. Kleinrok Z, Matuszek M, Jesipowicz J, Matuszek B, Opolski A and Radzikowski C: GABA content and GAD activity in colon tumors taken from patients with colon cancer or from xenografted human colon cancer cells growing as s.c. tumors in athymic nu/nu mice. J Physiol Pharmacol 49: 303-310, 1998.
9. Matuszek M, Jesipowicz M and Kleinrok Z: GABA content and GAD activity in gastric cancer. Med Sci Monit 7: 377-381, 2001.

10. Ortega A: A new role for GABA: inhibition of tumor cell migration. Trends Pharmacol Sci 24: 151-154, 2003.

11. Azuma H, Inamoto T, Sakamoto T, et al: Gamma-aminobutyric acid as a promoting factor of cancer metastasis; induction of matrix metalloproteinase production is potentially its underlying mechanism. Cancer Res 63: 8090-8096, 2003.

12. Joseph J, Niggemarm B, Zaenker KS, et al: The neurotransmitter gamma-aminobutyric acid is an inhibitory regulator for the migration of SW 480 colon carcinoma cells. Cancer Res 62: 6467-6469, 2002.

13. Liu CH, Huang $\mathrm{Q}$ and Wang C: Gamma-aminobutyric acid-induced apoptosis and effect of telomerase activity of cholangiocarcinoma cell line QBC939. Chin J Hepatobiliary Surg 15: 41-44, 2009.

14. Wang SG, Han BL, Duan HC, et al: Establishment of the characteristics of a cell line of extrahepatic cholangiocarcinoma. Chin J Exp Surg 14: 67-70, 1997.

15. Ries C, Loher F, Zang C, Ismair MG and Petrides PE: Matrix metalloproteinase production by bone marrow mononuclear cells from normal individuals and patients with acute and chronic myeloid leukemia or myelodysplastic syndromes. Clin Cancer Res 5: 1115-1124, 1999.

16. Stetler-Stevenson WG and Kleiner: Molecular biology of cancer: invasion and metastases. In: Cancer Principles and Practice of Oncology. 6th edition. Devita VT, Hellman S and Rosenberg SA (eds). Lippincott Williams Willkins, Philadelphia, pp123-136, 2001.

17. Hanahan D and Weinberg RA: The hallmarks of cancer. Cell 100: 57-70, 2000.

18. Chanda R and Ganguly AK: Diamine-oxidase activity and tissue di- and poly-amine contents of human ovarian, cervical and endometrial carcinoma. Cancer Lett 89: 23-28, 1995.

19. Nicholson-Guthrie CS, Guthrie GD, Sutton GP and Baenziger JC: Urine GABA levels in ovarian cancer patients: elevated GABA in malignancy. Cancer Lett 162: 27-30, 2001.

20. Coussens LM, Fingleton B and Matrisian LM: Matrix metalloproteinase inhibitors and cancer: trials and tribulations. Science 295: 2387-2392, 2002. 